\title{
GEOLOGISTICS: AN EMERGING NOTION IN MARITIME SUPPLY CHAIN
}

\author{
NUR HIDAYATI ABDUL KARIM*1 ${ }^{* 1}$ JAGAN JEEVAN ${ }^{1}$, NURUL HAQIMIN MOHD SALLEH ${ }^{1}$, \\ IZYAN MUNIRAH MOHD ZAIDEEN ${ }^{1}$, MASHA NUR SALSABIELA MENHAT ${ }^{1}$ AND TAYLOR \\ TAE HWEE LEE ${ }^{2}$
}

${ }^{I}$ Faculty of Maritime Studies, Universiti Malaysia Terengganu, 21030 Kuala Nerus, Terengganu, Malaysia
${ }^{2}$ Dept of Distribution, Gyeongnam National University of Science and Technology, South Korea

*Corresponding author: p4651@pps.umt.edu.my

http://doi.org/10.46754/jml.2021.08.003

\begin{abstract}
In line with the passage of time and the growing proliferation of technology, modern trends and prospects for logistics development have been defined in this paper. Effectively managing resources assists on suitable development approach to consistent and balancing all the resources that already exists. This is because the effective resource management manages to improve insight into resources availability as well as improves to the better, not only on environmental but also in profitability and human balance. Concerning to the modern concept in logistics, this paper aims to generalise and analyse the main concept of modern logistics development concept which called geologistics and the importance of the emergence of this concept in maritime perspectives. Therefore, the systematic literature review approaches have been employed. This paper evaluated journal or review articles based on the title, abstract, and keywords published in over the decades until the recent years. Thus, the result was reviewed in this paper are the definition of geologistics concept which can be define as utilising the existing resources in particular location by optimising an innovative approach in the supply chain for continues supply for human need, the importance of geologistics that could help in the global of process of manufacturing and services, and the overview of comparison between the green logistics and geologistics.
\end{abstract}

Keywords: Logistics, geologistics, green logistics sustainability

\section{Introduction}

The maritime transport industry has faced numerous environmental challenges in the last decade, including the shifts in trade patterns, the larger size of the vessels, intensive competition, port privatisation, intramodality as well as the global expansion of maritime transport operation (Lee, 2010). Logistics are known for represention of a chain of activities indicate known as a supply chain from suppliers, manufacturer, and distributors to retailer (Rodrigue, 2020). The application of logistics management also known for increasing the competitiveness for industry by affecting the practical costs of commodity movement and revenue from the sale of goods (Baginova \& Fedorov, 2020). The function of logistics will able greater efficiency in terms of scheduling, routes, terminals and modes (Rodrigue, 2020). Thus, one of the emerging concepts of logistics is known as geologistics. Geologistics is the concept which devote all knowledge for the goal of utilising the resources of the world for the benefit of mankid (Sachaklian, 2012). The geologistics involving three phases which are classified that links producers, suppliers, manufacturers, and distributors to retailers (Rodrigue, 2020). The application of logistics management concepts can increase the competitiveness of an industry by affecting the practical costs of commodity movement and revenue from the sale of goods (Baginova \& Fedorov, 2020). The function of logistics will enable greater efficiency in terms of the movement of goods and services via a choice of scheduling, routes, terminals and modes (Rodrigue, 2020).

In the context of globalisation and increasing demand for quality of goods and services, national enterprises are always searching for the new logistics ideas that would help to decrease general costs and optimise processes 
(Pytulyak, 2014). The modern concept of logistics development called geologistics, aims to focus on this. Available literature discusses the evolution of logistics and the application of geologistics concepts. Owing to the lack of academic research on geologistics, only five relevant articles were selected.

By dedicated simulation software, the complexity of logistics can be modelled, analysed, visualized, and optimized (Li, 2014).

\section{Literature Review}

The geography is a discipline that covers both natural and social sciences and it has the natural benefit of allowing for the transdisciplinary study of sustainability (Fu, 2020). Generally, the terms of geology come from the Ancient Greek $g \bar{e}$ (earth) and -logia (study of/discourse). Thus, geology is the study of the origin, structure, composition, and history of earth. Geologists clarify rocks and fossils to unravel Earth's 4.5 billion years history. They also look at the distribution and evolution of organisms on the planet and how that is changed. Geology is also a study of Earth's internal structures, as well as its surface landforms, and the processes that form them. Even on a more basic level, the fact is all of people have directly interacted with geology in everyday life.

The definitions of logistics have evolved over time because its functions and interest areas got changed (Szymańska et al., 2017). In general, logistics refers to describe the entire process of materials and goods moving into, through and/or out of a company. Logistics consists of any activity required in the management of inventory-at-rest awaiting production into finished goods, or distribution at the final point of sale, or in motion during transportation from one point origin to the final destinations for customers or corporation (Li, 2014). Physical items such as food, materials, animals, machinery, and liquids, as well as abstract items, such as time, knowledge, particles, and energy, are among the resources handled in logistics. Logistics includes all the activities involved in the information exchange, transport service, inventory management, warehousing, cargo handling and packaging (Kondratjev, 2015). By dedicated simulation software, the complexity of logistics can be modelled, analysed, visualized, and optimized (Li, 2014).

Figure 1 shows the evolution of logistics from Era 1 to 6 . Era 1 was beginning in 1916 to 1940 known as farm to market, following by Era 2 on 1940 to 1960 which is the segmented functions. This evolution continued as integrated functions in 1960 to 1970 (Era 3). Furthermore, customer focus was introduced on Era 4 by 1970 to 1985 . This era of evolution was focusing on the logistics as a differentiator in 1985 to 1997 (Era 5) Acordingly, Sheffi and Klaus, (1997) noted that logistics was only concerned with the optimising the three P's which is namely place (location and destination) in creating value for the customers by moving goods between locations which will achieve the best value to the customers. Secondly, the period and pace (time value) in build the value for customers by focusing on time. This is reflected in inventory management with the flow of goods. Thirdly the behavioural and boundary spanning was introduced on Era 5. Accordingly, Sheffi and Klaus (1997) noted that logistics was only concerned with the optimising the three P's namely place (location and destination) in creating value for the customer by moving goods between locations which will achieve the best value to the customer. Secondly, the period and pace (time value) it build the value for customers by focusing on time. This is reflected in inventory management with the flow of goods and thirdly, pattern which is forms of order, is the value creation through ordering by concentrating on the desired form of goods.

The growth of the logistics in this period was mostly for military purposes but it shifted to business organizations in the 1960s (Ballou, 2006). However, it was only concerned on the optimising transportation and not personnel an organisation, which was aided by the machining of transportation tools. During the 1980s, company began to deal with each other to control 


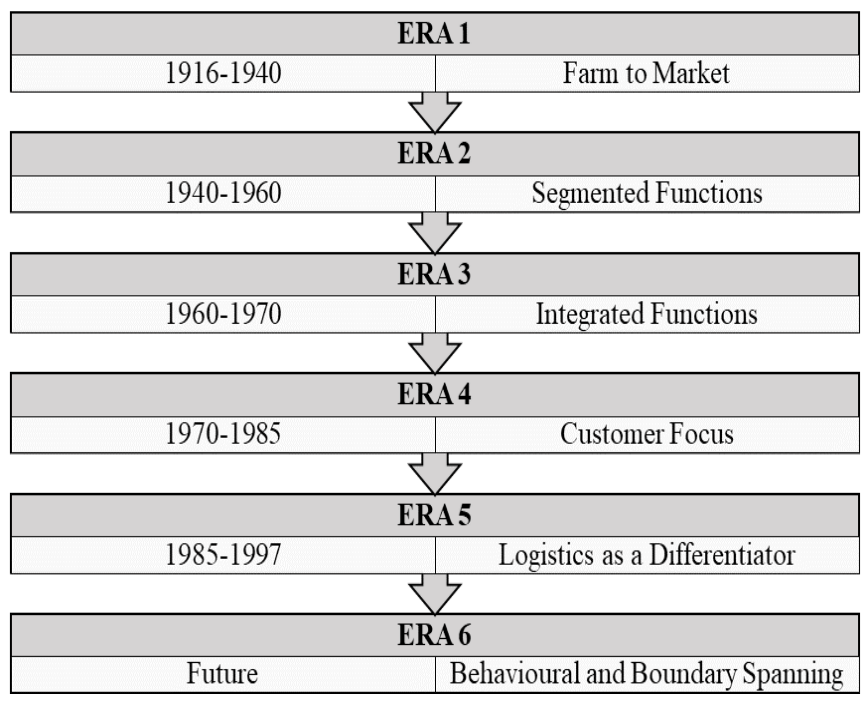

Figure 1: The evolution of logistics

Source : Adapted from Szymańska et al. (2017)

and organise physical flow on both inside and outside organizations and giving rise to the term of Supply Chain Management (Eljazzar et al., 2018; Lummus \& Vokurka, 2000).

In 1968, the industrial revolution started when the first industrial robot was produced. It was also during this period, the Numerically Controlled (NC) machines were introduced to the industry. On the logistics front, the "Systems of logistics management" ushered in the third logistical revolution (Galindo, 2016) Moreover, logistics and supply chain within industry in new era can be called as collaborative cyberphysical systems (Ivanov et al., 2016). Cyber Physical Systems (CPS) are described by the German Committee of Experts on Industry 4.0 as systems that causally link real physical objects and processes through open, partially global and often interconnected information networks (Bartodziej, 2017).

The development of logistics is influenced by six factors which is the innovations implemented in industry, IT technologies and technological economic, political, social or environmental factors (Szymańska et al., 2017). The logistics system is becoming increasingly important in the society activities whether involving the business or daily routine activities. Transportation and logistics system in new era have interdependent relationships that logistics management needs new technology on the transportation to perform its activities and in a meanwhile, a successful logistics system could help to improve the transportation development and traffic environment.

According to the literature sources, there are limited research on the geologistics especially in maritime industry perspective. Besides that, the gap on the literature is mostly in the Ukraine languages. The summary of the researchers focused on the geologistics concept are shown in Table 1. Generally, geologistics is derived from the Greek words (geo) meaning earth or pertaining to the earth and logistikos meaning calculation or accounting. Thus, geologistics are simply refer to the calculations of the earth and its resources. Geologistics are defined as being a broad term used to characterise the process of concentrating all knowledge for the purpose of utilizing the resources of the world for the welfare of mankid (Sachaklian, 2021).

Lussault (2011) explained the contemporary geologistics word. This paper defines the five elementary competence of spatiality that include 
Table 1: Application of geologistics concept from previous research

\begin{tabular}{|c|c|}
\hline Authors and Years & Key Components \\
\hline Lussault (2011) & $\begin{array}{l}\text { Define five elementary competences of spatiality which is the metric } \\
\text { control, the competence of positioning and adjusting, the scalar } \\
\text { competence, the competence of articulation and delimitation, and the } \\
\text { competence of crossing. }\end{array}$ \\
\hline Sachaklian (2012) & $\begin{array}{l}\text { The relationship between the geopolitics and the geologistics that are } \\
\text { focusing on human resources for better development and utilisation of } \\
\text { those resources. }\end{array}$ \\
\hline Pytulyak (2014) & $\begin{array}{l}\text { Generalise and analyse the main concepts of logistics, research } \\
\text { modern trends of logistics development and explain the directions of } \\
\text { improving and defining of the prospects for existing logistics concepts } \\
\text { development. }\end{array}$ \\
\hline Grytsevych and Senkiv (2017) & $\begin{array}{l}\text { Determine place of geology in the system of sciences in general, in } \\
\text { finding out its connection with the nearest scientific disciplines, social } \\
\text { geography and logistics. The authors examine conceptual and apparatus } \\
\text { of geologistics and formulated the subject of geologistics as a science, } \\
\text { as well as its relation to human geography. }\end{array}$ \\
\hline Wullur et al. (2020) & $\begin{array}{l}\text { Analyse the economic potentials of Halmahera Utara Regency with } \\
\text { Geo cluster, geologistics, and geostrategy variable approach that these } \\
\text { three variables named as geoclogs are still minimal terms discussed in } \\
\text { previous research. }\end{array}$ \\
\hline
\end{tabular}

Source: Compiled by authors

the metric control, the competence of positioning and adjusting, the scalar competence, the competence of articulation and delimitation and finally the competence of crossing. The quotidian exercise of these five competences configures the geologistics, which does not include only logistics traditionally construed, but every activity meant to handle the spatial environment, including individual geologistics efforts that present day societies increasingly require from their members.

Meanwhile, Sachaklian (2012), were interpret there are three major phases of geologistics which is the identification of resources, the inventory of resources and the technique of placing resources in motion to attain to the human aims (refer Figure 2). The identification the resources focusing on research on earth resources in turn requires to determine the area and the variety of such widely and utilized resources as the existence of iron and oil. For example, the vast area of North America remain comparatively unknown in terms of mineral and other resources that may exist. In recent years clues to the presence of massive quantities of oil have been discovered at the northern rim of the North American continent (Soeder, 2018).

This is the action of geologistics. After identifying and locating resources, the third step would be to place them in motion. All resources obtained must be utilized. It needs to be used thoroughly and be able to provide a profitable return. The acquisition can be measured in terms of the value of resources expended to bring in the new resources. Therefore, all available resources should be used comprehensively and efficiently. 


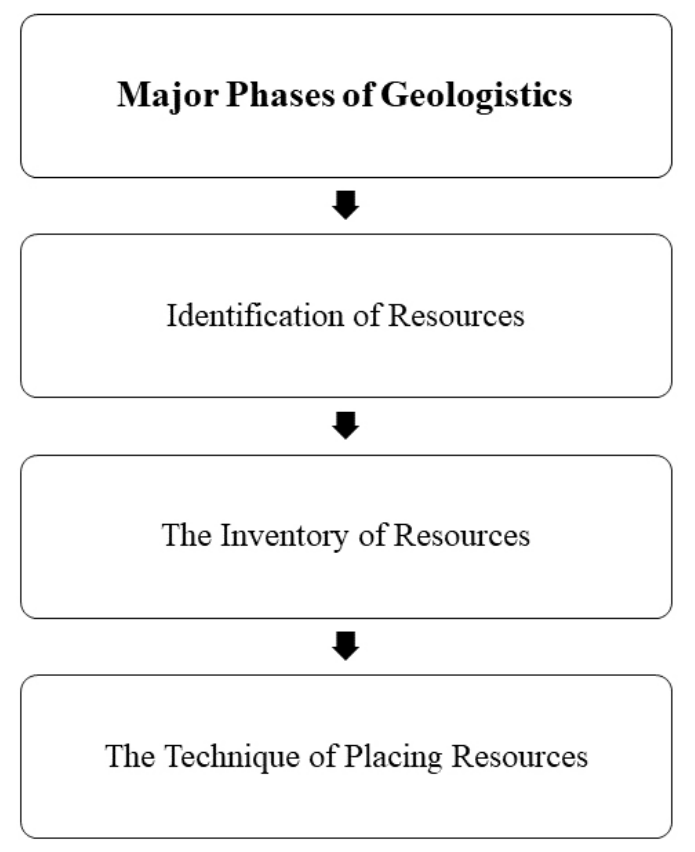

Figure 2: The major phases of geologistics

Source: Adapted from Sachaklian (2012)

Besides that, Pytulyak (2014) discussing on the Ukrainian and foreign scientists describe new logistics concept in their works, except those that are well-known. Particularly, it is being analyse insome researcher the development of logistics concepts, such as geologistics, "green" logistics. Pairing with the development of logistics concepts, every stage of the development of this science is accompanied with the appearance of new organization and economic forms as well as new types of logistics. The first consulting logistical forms establishing the ground society and geographical logistics, also known as geologistics, appeared in the beginning of XXl century.

The main aim was to optimise economic processes occurring on a microlevel. This refers to the possibility and necessity of logistics application in regional programs of development of national economies, and to increase efficiency of international economic relations. It is evident that today the development of society causes emerging of new directions of logistics and logistics concepts, such as geologistics, reverse logistics, "green" logistics, ecologistics. In our opinion, the most perspective direction of logistics development is ecologistics, the main principles and aims of which are on the stage of formation and concept of this direction of logistics needs scientific proof.

Grytsevych and Senkiv (2017) analyse in the paper on the geological research in Ukraine which is developed theoretical and practical bases of logistic direction and the integration into the Europe transport and logistic system. Also, Grytsevych and Senkiv take a territorial logistics sytem (TLS) as the object research of geology. The territorial logistics system (TLS) is an interconnected network of specialised business entities and infrastructure, linked by territorial community, for efficient folow of passenger, freight, information and financial. TLS is a functional component subsystem of the territorial economic system which is can be regional, interregional, national and international area. 
Apart from that, for the past year geologistics are being discussed as geoclogs by Wullur et al. (2020). Geoclogs as a new concept integrates three economic spatial planning variables which is geo cluster, geologistics, and geostrategy (Wullur et al., 2020). In this paper, Wullur are discussing on the economic potentials of the Halmahera Utara Regency with these three variables. Regarding to Wullur, geologistics is the earth science that learns the management process from the transfer and storage of goods and information related to the source of the end consumer effectively and efficiently. News, finance and materials, and logistics reserves.

\section{Methodology}

This research adopted a three-stage approach to identify and to evaluate research on geologistics published in journals (refer Figure 3). In the first stage, a literature study was initially collect to get the concept of the geologstics from any article, journal, report, conference and related. Scopus is considered as one of the world's largest sources for peer-reviewed articles ranging from books, book chapter, review, conference proceedings, and journal articles covering over 70 million items from various sectors and research backgrounds. Initially, the researchers conducted some keywords required to do the search for the articles in Scopus as well as the exclusion to retrieve best results in line with the researchers' needs. This paper evaluated journal or review articles based on the title, abstract, and keywords published in over the decades until the recent years. The articles should have been written in English and categorized as journal articles. This study included publications from conference proceedings and books because the very limited on the sources regarding to this topic. At the second stage, articles that match the search query were sorting to get the exact aim on the sources. In this terms, geologistics not well-known not only in Europe but also globally. At the last stage, a qualitative analysis was performed by taking the review thoroughly the concept of geologistic in order to get the three main point on this research.

\section{The Definition Of Geologistics}

The context directions of geologistics research are decided upon in the article based on domestic and foreign research literature in logistics and geologistics. It has been discovered that, unlike logistics, the idea of geologistics is still underdeveloped both in Ukraine and abroad (Grytsevych \& Senkiv, 2017). Based on the limited literature on geologistics concept, it can be seen the definition of the geologistics can be comprises as the integration between the resources around the world (earth) and the logistics flow that include the process of all the logistics element. Thus, geologistics is how the global process of manufacturing and services moved from upstream to downstream, built with the confidence, determination, and action of each party along the displacement chain (Bowersox et al., 2013).

In fact, there are no clear unambiguous definitions that would link geology with related sciences, and there is also no unity of understanding main terms of geology (Grytsevych \& Senkiv, 2017). In the past literature, researcher still have no clear identification on the geologistics concept as it is still not universally known in any area especially in maritime. Although, there is a lack on the sources of the literature it still have some sources that might help to get some ideas on how the geologistics concept should be interpret (Wullur et al., 2020; Grytsevych \& Senkiv, 2017; Pytulyak, 2014; Sachaklian, 2012; Lussault, 2011). Thus, this is the reason on why this concept (geologistics) was are not being used extensively especially in the maritime nations of the world. Hence, in this paper, based on the previous literature, the concept of geologistics can be define as utilising the existing resources in particular location by optimising an innovative approach in the supply chain for continues supply for human need.

\section{The importance of geologistics Concepts}

There are ten general categories of environmental and geographic factors that must be focusing 


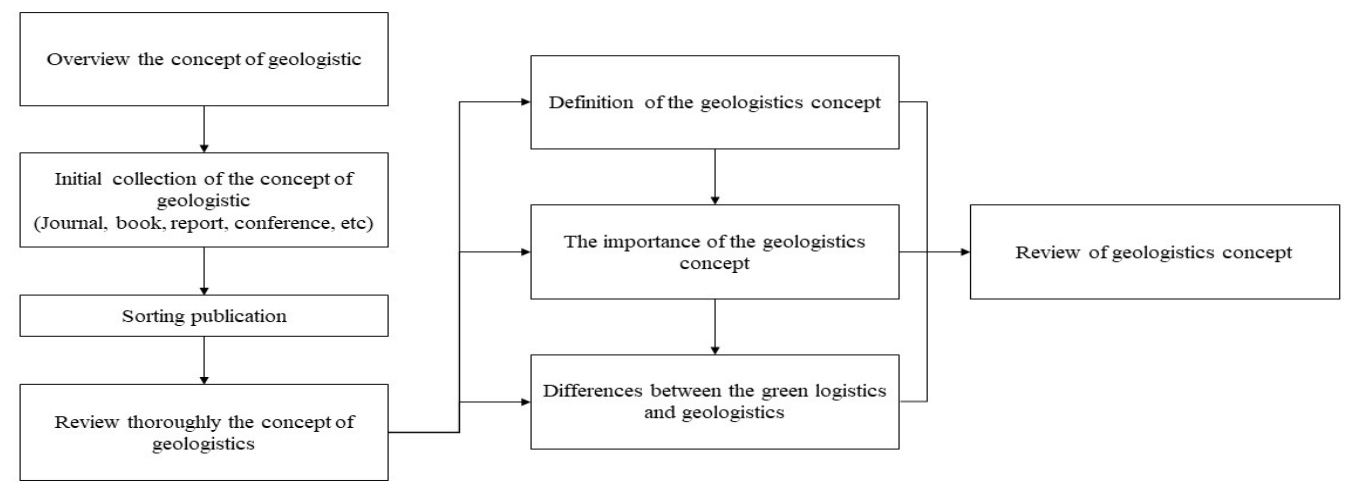

Figure 3: Flowchart of the literature screening methodology used in this review

Source: Authors

which is the land mass, the water areas, climate, political, economic, and social organisation, manpower resources, agricultural and forest resources, mineral resources, transportation capabilities, fuel and power and industrial development (Sachaklian, 2012). Among this component, geologistics concept are seen could be implement in the maritime sector such as in seaport and inland port. The focusing on the resources of land and earth, this concept could help to comprising the basic sustainable component which is based on the triple bottom line (BTL); people, planet, and profit and also called as economic, social and environmental (Geerts \& Dooms, 2020; Sislian et al., 2016; Adams et al., 2009). As noted by I. G. (2019), geologistics is the earth science that learns the management process of the transfer and storage of goods and information related to the souce of the end consumer with effectively and efficienctly. Thus, geologistics concept could help in global process of manufacturing and services that moved from upstream to downstream, create with trust, commitment, and action of every party along the displacement chain especially in maritime supply chain.

\section{The Differences Between The Green Logistics And Geologistics}

In the new globalisation and development in the world, government officials, academic researchers, businesses, multinational corporations, policymakers, and other stakeholders in supply chain management (SCM) are concerned about logistics operations in terms of their sustainable development (Li et al., 2021). It is importance to ensure the environmentally stability in order to save the planet (environment), people (social) and the profit (economy) for the future generation. Thus, there are many concepts in order to get a clear vision on how some development could give a benefit to all but also to the earth.

Traditionally, logistics encompasses the business process that plan, control, and implement the flow of goods between points of origin and point of consumption to meet customer demand (Blanco \& Sheffi, 2017). It has been driven by minimising cost, maximising profitability, or achieving customer targets (Blanco \& Sheffi, 2017). Inside the framework of logistics and environmental quality, green logistics serves as the key factor in managing green and sustainable supply chain, and, in effect, green logistics is considered a forerunner to the component of green supply chain management (Fahimnia et al., 2015). Thus, managing economic performance and environmental quality in logistics at the same time are challenging tasks; however, environmental sustainability implementation is important for sustainable development (Xiaolong Li et al., 2021). Apart 
from that, geologistics more focusing on the resources to be implement in the concept of the logistics itself. Therefore, it is evident that the development of society today causing the emergence of new directions of logistics and the logistics concept such as the green logistics and the geologistics (Pytulyak, 2014).

Table 2 shows the differences between green logistics and geologistics. Green logistics concept are efforts in measuring and minimise the environmental impact of logistics activities while geologistics are more on the calculation of the earth and its resources in order to ensure that all the resources can be explore, examined, and well managed. Thus, green logistics are focusing more on the eco-friendly resources and saving costs in the market. While geologistics includes in identified any of resources and managed all the existing resources efficiently. Both terms can be included in the sustainability goals that had been added in this new era of the business objectives especially in maritime transport as there has been an increased interest in mitigating the social and environmental impact of the goods and operations (Blanco \& Sheffi, 2017).not been formed. There is no generalized opinion as to definitions of the main terms and natures of this scope.
Today the development of logistics concepts is underway, and one of the main promising directions is ecologistics. Researchers have revealed that, there is no distinct and unified definition of ecologistics as it is often equalled with "green" logistics. Many interpretations witness about the development of ecologistics, gradual formation of its main principles, aims and concepts. Foreign and national scientists regard ecologistics not only as a new direction of logistics, but also as one of the factors of its constant development, intricately connecting it with ecology. As a result, researchers are unable to access rigorous and reliable article on the geologistics concept. Due to the current lack of comprehensive understanding in geologistics concept, future research should address this new trend of the concept. This concept is interested to be use and implement in the other region in order to balance and help in sustainability especially in the maritime area such as for the seaport and inland port development in future. It provides a new contribution on literature especially on maritime logistics and the validation of the findings in this paper is worth to be explore in future.

Table 2: The differences between green logistics and geologistics

\begin{tabular}{lll}
\hline \multicolumn{2}{c}{ Green Logistics } & \multicolumn{1}{c}{ Geologistics } \\
\hline Concept & $\begin{array}{l}\text { Efforts to measure and minimize the } \\
\text { environmental impact of logistics }\end{array}$ & $\begin{array}{l}\text { The calculation of the earth and its resources } \\
\text { that need to be explore, examined and well- } \\
\text { activities, these activities include a } \\
\text { proactive design for disassembly. }\end{array}$ \\
Focusing Point & $\begin{array}{l}\text { Necessity on searching for ways to } \\
\text { harmonise the goals of sustainable } \\
\text { development and logistics. }\end{array}$ & $\begin{array}{l}\text { The earth science mainly the resources } \\
\text { that learns the management process from } \\
\text { the transfer and storage of goods and } \\
\text { information related to the source of the end } \\
\text { consumer with effectively and efficiently. }\end{array}$ \\
& $\begin{array}{l}\text { Mitigate environmental externalities in } \\
\text { logistics activities such as reducing of } \\
\text { consumption of non-renewable energy } \\
\text { factors such as the land mass, the water } \\
\text { areas, climate, political, economic, and } \\
\text { sources, air emissions, greenhouse gas } \\
\text { emissions, and waste. }\end{array}$ & $\begin{array}{l}\text { social organisation, manpower resources, } \\
\text { resources, transportation capabilities, fuel } \\
\text { and power and industrial development. }\end{array}$ \\
\hline
\end{tabular}




\section{Conclusion}

The systematic literature review that set the tone for the articles in this concept of logistics found only 5 relevant articles over the several yeras in Ukraine. Previous systematic literature reviews on the geologistics concept in Ukraine region are very few and they similary found relatively small number of relevant scientific publications. Although the volume of research in the logistics in the Europe has increased over the years, there are still insufficient data on the new trends in logistics, ecologistics, geologistics and reverse logistics be use in another region. Despite the unique ability of logistics to increase efficiency of business activity of enterprises, theoretical background of this young science in Europe has not been formed. There is so generalized opinion as to definitions of the main terms and natures of this scope.

\section{Acknowledgements}

Authors wish to thanks the reviewers for the constructive comments and the university for the research opportunity.

\section{References}

Sachaklian, H. A. (2012). Geopolitics versus Geologistics. 2(2), 53-63.

Adams, M., Quinonez, P., A.Pallis, A., \& H. Wakeman, T. (2009). ENVIRONMENTAL issues in port competitiveness. Dalhouse University.Atlantic Gateway Initiative Centre for International Trade and Transportation Working Paper 7, 7, 3.

Baginova, V., \& Fedorov, L. (2020). Logistics as a factor of increasing competitiveness of a company. E3S Web of Conferences, 217. https://doi.org/10.1051/ e3sconf $/ 202021707019$

Ballou, R. H. (2006). The evolution and future of logistics and supply chain management. Produção, 16(3), 375-386.
Bartodziej, C. J. (2017). The concept industry 4.0. the concept industry 4.0, 2011. https:// doi.org/10.1007/978-3-658-16502-4

Blanco, E. E., \& Sheffi, Y. (2017). Sustainable supply chains: chapter 7 - green logistcs. In green supply chain management for sustainable business practice (Volume 4). https://doi.org/10.4018/978-1-5225-06355.ch001

Bowersox, D. J., Closs, D. J., Cooper, M. B., \& Bowersox, J. C. (2013). Supply chain logistics management (4th Ed.). McGrawHill Companies.

Eljazzar, M. M., Amr, M. A., Kassem, S. S., \& Ezzat, M. (2018). Merging supply chain and blockchain technologies. ArXiv, 1-6.

Fahimnia, B., Bell, M. G. H., Hensher, D. A., \& Sarkis, J. (2015). Green logistics and transportation: Chapter 5 green transport fleet appraisal. In Green Logistics and Transportation: A Sustainable Supply Chain Perspective (pp. 1-12). Green Supply Chain Management. https://doi.org/10.1007/9783-319-17181-4_1

$\mathrm{Fu}$, B. (2020). Promoting geography for sustainability. geography and sustainability, 1(1), 1-7. https://doi.org/10.1016/j. geosus.2020.02.003

Galindo, L. D. (2016). The challenges of logistics 4.0 for the supply chain management and the information technology. norwegian university of science and technology, May, 1-84. https://brage.bibsys.no/xmlui/ bitstream/handle/11250/2396477/15993 FULLTEXT.pdf? sequence $=1 \&$ is Allow ed $=y \% 0$ Ahttps://brage.bibsys.no/xmlui/ bitstream/handle/11250/2396477/15993 FULLTEXT.pdf?sequence $=1$

Geerts, M., \& Dooms, M. (2020). Sustainability reporting for inland port managing bodies: A stakeholder-based view on materiality. Sustainability (Switzerland), 12(5). https:// doi.org/10.3390/su12051726 
Grytsevych, V., \& Senkiv, M. (2017). Conceptual and terminological basics of geologistics as an actual direction of human geography. Ekonomichna Ta Sotsialna Geografiya, 78, 53-59. https://doi.org/10.17721/24137154/2017.78.53-59

I. G., S. (2019). Geologistic Strategies of tourist and hotel \& restaurant business development in Overtourism Conditions. Scientific Bulletin of Kherson State University. Series Geographical Sciences, 10, 86-96. https:// doi.org/10.32999/ksu2413-7391/2019-1012

Ivanov, D., Dolgui, A., Sokolov, B., Werner, F., \& Ivanova, M. (2016). A dynamic model and an algorithm for short-term supply chain scheduling in the smart factory industry 4.0. International Journal of Production Research, 54(2), 386-402. https://doi.org/1 $0.1080 / 00207543.2014 .999958$

Kondratjev, J. (2015). Logistics transportation and Warehouse in Supply Chain. Centria University of Applied Science, Finland. Retrieved from https://www.theseus. fi/bitstream/handle/10024/91465/Eng_ Thesis_Final.pdf?seq

Lee, E. S. (2010). Knowledge resource in maritime transport industry : A case analysis. Asian Journal of Shipping and Logistics, 26(2), 297-340. https://doi.org/10.1016/ S2092-5212(10)80007-0

Li, X. (2014). Operations management of logistics and supply chain: Issues and directions. Discrete Dynamics in Nature and Society, 2014. https://doi.org/10.1155/2014/701938

Li, X, Sohail, S., Majeed, M. T., \& Ahmad, W. (2021). Green logistics, economic growth, and environmental quality: evidence from one belt and road initiative economies. Environmental Science and Pollution Research. https://doi.org/10.1007/s11356021-12839-4
Lummus, R. R., \& Vokurka, R. J. (2000). Defining supply chain management: A historical perspective and practical guidelines. Value in Health, 3(1), 11-17.

Lussault, M. (2011). On Contemporary "Geologistics". Ambiente, ambientamento, ambientazione, 9, 43.

Pytulyak, N. (2014). Modern Trends and Prospects for Logistics Concepts Development, 464-476.

Rodrigue, J.-P. (2020). 7.4 - Logistics and freight distribution | The geography of transport systems. Retrieved March 31, 2021, from https://transportgeography.org/contents/ chapter7/logistics-freight-distribution/

Sislian, L., Jaegler, A., \& Cariou, P. (2016). A literature review on port sustainability and ocean's carrier network problem. Research in Transportation Business and Management, 19, 19-26. https://doi. org/10.1016/j.rtbm.2016.03.005

Soeder, D. J. (2018). The successful development of gas and oil resources from shales in north america. Journal of Petroleum Science and Engineering, 163(January), 399-420. https://doi.org/10.1016/j.petrol.2017.12.084

Szymańska, O., Adamczak, M., \& Cyplik, P. (2017). Logistics 4.0 - A new paradigm or set of known solutions? Research in Logistics and Production, 7(4), 299-310. https://doi. org/10.21008/j.2083-4950.2017.7.4.2

Wullur, M., Kumaat, J. C., \& Lonto, A. L. (2020). Geoclogs: The potential of a special economic zone in halmahera utara regency, 473(Icss), 194-199. https://doi.org/10.2991/ assehr.k.201014.043 